\title{
The Study of Strategies in Learning English and English Academic Achievement
}

\author{
Noor Hayati \\ Sekolah Tinggi Agama Islam Samarinda \\ yatielyaman@gmail.com \\ Usman \\ Madrasah Aliyah Negeri 2 Samarinda \\ Usman.elyaman@gmail.com
}

\begin{abstract}
English language learning is not a new thing in Indonesia, many people want to learn English for different purposes. However, some students cannot achieve their goals easily or follow the learning process smoothly. One of the factors causing this problem is the strategy used in language learning. This research aimed at investigating the correlation between English language learning strategies and English academic achievement. This study used a descriptive and correlational design, as well as quantitative and qualitative methods. The English scores of the students on their study report (KHS) and SILL were used as the instrument. The participants in this study were fifty third-year English majors at IAIN Samarinda. Three students were also picked to participate in a semistructured interview. After that, descriptive and Pearson Product Moment correlations were used to assess the research data. The pupils' preferred strategy was social strategy, according to the findings. The association between students' English language learning practices and English academic achievement was found to be significant at $r=.436$, $\mathrm{p}=.001 .05$.
\end{abstract}

Keywords: English Academic Achievement; English Language Learning Strategy; Strategies Inventory for Language Learning (SILL). 


\section{INTRODUCTION}

Learning a language is the way to comprehend and be proficient in a certain language, certain people might learn very rapidly and well during the learning process while others have problems in learning, then both students and teacher should be able to find the solution for such problem. Many factors influence the outcomes; one of them is learning strategy. If the students find the appropriate strategies to learn, They will be able to direct their education (Griffiths, 2004).

Over the years, many researchers have shown some definitions of Language Learning Strategies (LLS). Strategies are specialized approaches to a problem or modes of operation for accomplishing a specified and planned design for controlling and manipulating certain information. The method through which an instructor decides to deliver information and aid learning is referred to as a teaching strategy(Apriani, 2017). Rubin (1975:43) in (Griffiths, 2004:2) defines that learning strategies referred to the techniques or devices used by the learner to obtain knowledge. Learning strategies, according to Oxford (1990) cited in (Kuo Lee, 2010), are the specific actions learners adopt to make learning more convenient, faster, pleasant, self-directed, successful, and applicable to other contexts. Furthermore, (A. Chamot, 2004) defines learning strategies as ideas and activities used to attain the goal of learning. Lee offers another definition: learning strategy is the ability to learn, learn to learn, think critically, and solve problems. (Kuo Lee, 2010). Then, (Suwanarak, 2012) finds that strategies for language learning are the concerted effort that the learners do in learning language and it is related to the characteristics of the learners, the styles, and the achievement of learning. Additionally, Oxford (1990) in (D. H. Brown, 2007; Griffiths, 2004; Rebecca L Oxford, 2003a; Richards et al., 2002; Sioson, 2011; Solak \& Cakir, 2015; M.-H. M. Su, 2005; Uslu et al., 2016) classifies learning strategies into two groups; direct strategy and indirect strategy, these two groups were then subdivided into six categories; memory, cognitive, and compensation strategy, metacognitive, affective, social strategy.

According to (Rebecca L Oxford, 2003a), one of the most important aspects in deciding how and how successful individuals acquire a second or foreign language is their language learning strategy. It is the following (A. Chamot, 2004) who states, according to several experts, students' Learning strategies are an excellent way to assist struggling language students in improving their performance. (Rebecca L Oxford, 2003a) says, when the learner uses the appropriate learning style consciously, The strategies have proven to be an effective method for active, aware, and 
purposeful learning self-regulation. In general, learning strategies are concerned with the reception, storage, and retrieval of signals from those around. Similarly, Abraham and Vann (1987) and Vann and Abraham (1990) in (M.-H. M. Su, 2005) believe that The degree of students' flexibility in selecting strategies and the learners' capacity to effectively use strategies in their learning setting is the distinction between successful and less successful learners.

Another point to note when conducting this research is that some academics have looked into the association between students' learning styles and academic accomplishment, but the results have been inconsistent. Studies conducted by (Al-Hebaishi, 2012a; Al-Qahtani, 2013; Angelianawati, 2012; Ghavamnia et al., 2011; Jhaish, 2010; Solak \& Cakir, 2015; Suwanarak, 2012; Uslu et al., 2016), discovered that students' language learning practices affected significantly to the participants' academic achievement. In contrast, the research by (Sioson, 2011) has shown that in general, language learning strategies had an insignificant correlation with the academic speaking task.

In the light of those considerations, the researcher has found clearly that It's critical to understand the learners' preferred strategies in learning language and practically encourage them to use appropriate strategies to get success in learning a certain language, in this case, English. Also, this research is to verify whether the correlation exists between both variables in this study and, if so if the correlation will be significant or insignificant.

\section{THEORETICAL FRAMEWORK}

\section{Academic Achievement}

A classroom lesson, unit, or even the entire curriculum is directly related to an achievement test (D. Brown, 2007). Another definition is based on Collin Cobuild Advanced Learner's English Dictionary (2006) which states that Someone's achievement is something they have accomplished, especially after spending a great deal of effort.

Students' achievement in university or higher education is usually reflected by their scores on formative tests - commonly given by lecturers after students have studied one or two basic competencies -, mid-semester tests - administered after three months of study -, and a final or semester test - usually administered at the end of the semester. The final achievement of students in each semester for each topic is usually measured by their score in the "Kartu Hasil Study" report (KHS). Furthermore, students' final grades for all subjects in each semester are normally calculated using their Grade Point Average (GPA), and students' cumulative grades for all semesters are 
calculated using their Cumulative Grade Point Average (CGPA). The researcher used the students' fifth-semester English subject scores reflected on their study report (KHS) as a measure of the English department students' achievement in this study.

\section{Language Learning Strategy}

Regarding language learning strategies, over the years, several scholars have defined the term Language Learning Strategies (LLS) in various ways. Learning strategies, as defined by Oxford (1990) and cited in (Lee, 2010) Learning strategies, as defined by Oxford (1990) and cited in Lee (2010), are learners' particular activities to make learning easier, faster, more pleasant, more self-directed, more productive, and more transferable to other settings Learning strategies. Furthermore, (A. Chamot, 2004) are the ideas and activities people use to achieve a learning goal. Learning skills, learning-to-learn skills, thinking skills, and problem-solving abilities are all defined as learning strategies (Lee, 2010). Moreover, (Suwanarak, 2012) states that language learning strategies are what learners undertake to learn a language and are linked to learner qualities, learning styles, and achievement. In a brief, language-learning strategies are the specific actions that learners use to reach their learning goals in a more effective, enjoyable, faster, and easier manner.

\section{Classification of Language Learning Strategies}

Oxford (1990 in (D. H. Brown, 2007; Griffiths, 2004; Rebecca L Oxford, 2003a; Richards et al., 2002; Sioson, 2011; M. M. Su, 2005) classifies learning strategies into two major groups: direct and indirect, which are then further subdivided into six categories.

\section{Direct Strategy}

The term "direct strategy" refers to a strategy that directly involves the target language and necessitates mental processing of the language. This strategy assists learners in understanding, using, and producing language even when there is a knowledge gap or it is a new language. Memory, cognitive, and compensation strategies are all part of the direct strategy.

Memory strategies aid learners in remembering new language items and correlating one language or concept with another, but they do not require indepth comprehension. This strategy includes making mental connections (grouping, associating/elaborating, inserting new words into context), utilizing visuals and sounds (using imagery, semantic mapping, keywords, representing sounds in memory), reviewing thoroughly (structured viewing), and acting (using physical response or expression and mechanical techniques).

Following that, a cognitive strategy allows learners to manipulate linguistic content in direct ways while also assisting them in thinking about and understanding the target language. Cognitive strategies are classified into four types: (1) repetition, formal practice with sound and writing systems, 
recognition and application of formulas and patterns, recombination, and naturalistic practice; (2) receiving and sending messages, such as getting the idea quickly and using resources for receiving and sending messages; (3) deductive thinking, analyzing expressions, analyzing contrastively-across languages, translating, and transferring; and (4) input and output structure creation, which includes taking notes, summarizing, and highlighting.

As explained in Rubin (1991), major direct and indirect cognitive processes are discussed in a classification system (M. M. Su, 2005) Clarification, confirmation, monitoring, remembering, guessing/inductive reasoning, deductive reasoning, and practice are all examples of the direct cognitive approach. Creating opportunities for practice and using production methods such as communication strategies are examples of indirect cognitive approaches.

The last strategy is compensation, which aids learners in compensating for a lack of or insufficient grasp of the target language, mainly through grammatical and vocabulary deficits. Intelligent guessing (using linguistic or other cues) and overcoming speaking and writing limitations (switching to the mother tongue, getting help, using mime or gesture, avoiding communication partially or, selecting the topic, adjusting or approximating the message, coining words, using a circumlocution or synonym) are examples of these strategies In production, compensation mechanisms can also be used, especially when grammatical comprehension is lacking.

\section{Indirect Strategy}

The indirect strategy, which aids the learner in controlling the learning process, is the second major group of strategies. This strategy facilitates and oversees language acquisition without requiring direct participation. This category includes metacognitive, emotional, and social strategies.

First, a metacognitive strategy that goes beyond the cognitive mechanism and allows learners to coordinate their learning as well as regulate their cognition and plan language learning efficiently. This strategy consists of organizing and planning (learning about language learning, organizing, setting goals and objectives, identifying the purpose of a language task, planning for a language task, seeking practice opportunities), and evaluating learning (overview and linking with previously known material, paying attention, delaying speech production to focus on listening) (self-monitoring and evaluating). Students, for example, could develop a plan for tracking their progress by comparing their current level of competency to the course objectives in the curriculum.

The next technique is affective strategy, which involves identifying one's mood, emotion, attitude, motivation, and anxiety level concerning learning a new language. This category contains three types of strategies: reducing anxiety (through progressive relaxation, deep breathing, or 
meditation, as well as music and laughter), encouraging oneself (through positive statements, taking calculated risks, and rewarding oneself), and taking an emotional temperature (through positive statements, taking calculated risks, and rewarding oneself) (listening to your body, using a checklist, writing a language learning diary, discussing feeling with someone else). For example, students can read linguistically simplified books to foster a favorable attitude toward reading resources.

Finally, social strategy relates to the acts that learners use to interact with other language users, which aids learners in collaborating with others and comprehending both the target culture and the language. Questions (asking for an explanation, verification, and correction), cooperating (working with others and adept users of the new language), and empathizing with others (building cultural understanding, becoming aware of others' ideas and feelings) are all part of this technique. Students may, for example, actively seek out opportunities to speak the target language with native speakers.

To sum up, language-learning strategies can be involved in the language-learning process either directly or indirectly. These two types complement one another, and learners must use both to learn a language effectively. As a result, identifying the strategies used by learners in language learning is critical for the teacher to correct negative or inappropriate strategies held by the students.

\section{Factors Affecting the Use Language Learning Strategy}

Achievement or proficiency, course level, cultural background, age, and gender are all factors that influence language learners' choice and preference for learning strategies (Suwanarak, 2012). According to Oxford and Nyikos (1989), as cited in (Griffiths, 2004) f students' self-rating of proficiency levels is closely related to their use of language learning strategies. Similarly, (Suwanarak, 2012) discovered that students' English language learning achievement levels influenced the frequency of use and strategy selection. Furthermore, Griffiths (2003) in (Griffiths, 2004) discovered that advanced students use language-learning strategies more frequently than elementary students, particularly in terms of interaction with others, vocabulary, reading, ambiguity tolerance, language system, management of feelings and learning, and utilization of available resources.

Other factors that influence the use of language learning strategies include cultural background and nationality. Politzer \& McGroarty (1985) noticed that Hispanic students exhibited more of the strategies expected of "good" language learners than Asian students, while O'Malley (1987) in (Lee, 2010) attributes Asian students' lack of success to the persistence of familiar strategies. In terms of gender, Bacon's (1992) study, as cited in (D. H. Brown, 2007) revealed that men and women used listening strategies differently. Similarly, El-Dib (2004) in 
Hayati, Usman: The Study of Strategies In Learning English And English Academic Achievement - 353

(A. U. Chamot, 2004) discovered differences in strategy use between men and women in Kuwait based on the type of strategy rather than an overall difference

\section{RESEARCH METHODOLOGY}

This research was a kind of descriptive and correlational, quantitative-qualitative study to look into how the participants learned English. Additionally, this research is also to determine if there is a link between the strategies and academic accomplishment in English and if so, how significant the variables are related in a given population.

50 students of the third-year English education department students of IAIN Samarinda were chosen as the target population and sample and 3 students with the minimum, medium, and maximum English scores as the interviewees in the hope that they will represent other students in giving and providing information in persons about language learning strategies.

This study employed two types of data; quantitative and qualitative data. For quantitative data, students' English academic achievement measured by their fifth-semester scores of English taken from their study report (KHS), while students' English learning strategies determined by the Strategy Inventory for Language Learning (SILL) constructed by Rebecca Oxford (1990), in (Griffiths, 2004). SILL consists of 50 items grouped under six categories; memory, cognitive, compensation, metacognitive, affective, and social strategies. Even though numerous scholars have employed SILL extensively, (Al-Hebaishi, 2012b; Angelianawati, 2012; Ghavamnia et al., 2011; Hong-Nam \& Leavell, 2006; Jhaish, 2010; Lan, 2010; Liao \& Chiang, 2004; Saeb \& Zamani, 2013; Sioson, 2011; Solak \& Cakir, 2015; M.-H. M. Su, 2005; Suwanarak, 2012; Uslu et al., 2016; Yang, 1999), the researcher still firstly tried out this instrument, the Cronbach's Alpha was .919 which showed that validity and reliability of SILL were in an excellent level. Furthermore, for a better understanding of assessing the students' English language learning strategies and to get more information about the additional strategy they might have, the researcher used a semi-structured interview or in-depth personal interview for the qualitative data.

Strategy Inventory for Language Learning (SILL) was statistically analyzed using SPSS and each of the questionnaire items was answered on a five-point Likert scale. Pearson's Product Moment Correlation was then used to determine the relationship between students' academic achievement in English and SILL. The researcher used content analysis with Flow Activities to analyze the interview data, which includes three processes: data reduction, data display, and conclusion drawing. 


\section{RESULTS \& DISCUSSION}

\section{Results}

The Students' Preference of Using English language learning strategies

To determine the students' preferred English language strategies, descriptive statistics for direct and indirect strategies were calculated initially.

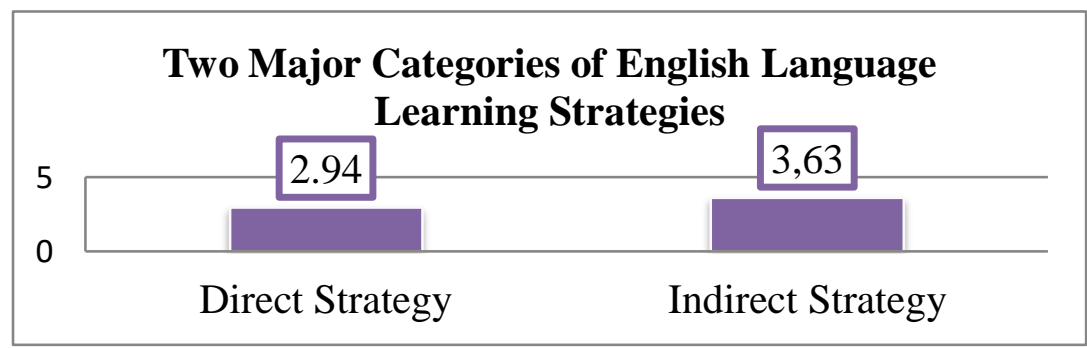

\section{Diagram 1. Two Major Categories of Learning Strategies}

The mean scores for overall SILL were 3.49, direct strategies were 2.94, and indirect strategies were 3.63. The findings showed that indirect strategies have contributed to regulating the learning process of the learners i.e. Social, metacognitive, and affective strategies were at the top of the participants' favored strategies list. While direct methods that help students learn, utilize, and generate language, such as compensation, were the least desired strategies by the participants,

The result is shown in the graphic below, which deals with the most often employed strategies among the six categories.: 


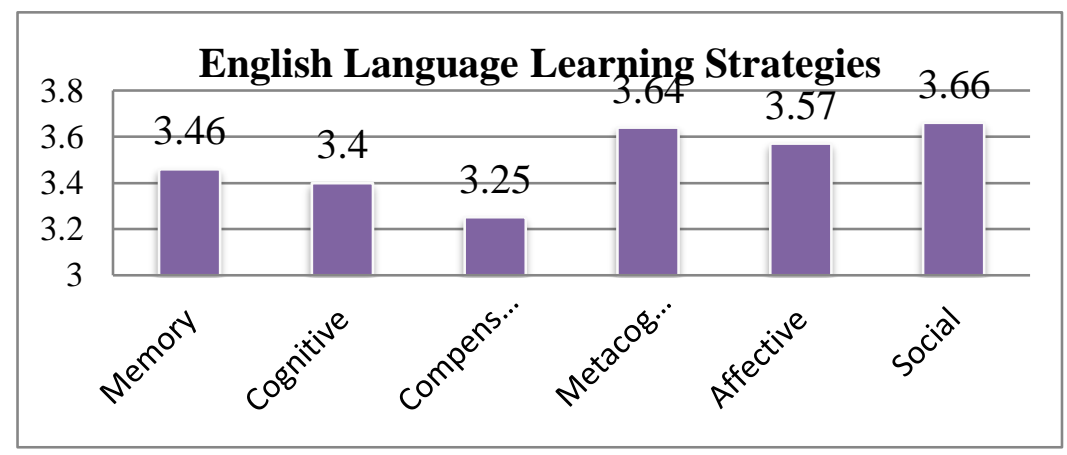

Diagram 2. English Language Learning Strategies

As can be seen above, with a mean score of 3.66, the most chosen strategy was the social strategy. With a mean of 3.64, metacognitive strategy came in second, followed by affective strategy (mean $=3.57$ ), memory strategy $($ mean $=3.46)$, cognitive strategy $($ mean $=3.40)$, and compensatory strategy (mean=3.25).

\section{Discussion}

The findings were in contradiction to (Uslu et al., 2016) but in line with (M.-H. M. Su, 2005), who found that social strategy was the students' favorite strategy. One of the actions in this technique was to ask others to talk slowly or repeat words or sentences if they didn't understand what was being said, and if possible, to ask native speakers of English to assist or correct their language while speaking. Additionally, learners may have preferred social methods due to the requirement to be a member of a group and collaborate with other students and teachers. Especially at the level where the current study's subjects were, establishing a relationship with others was deemed important because they were in the third year of college life who required to employ their knowledge in the social life which called Praktek Pengalaman lapangan (PPL) and Kuliah Kerja Nyata $(K K N)$ in the fourth year, moreover after finishing their undergraduate program, they will need to participate more in their work area and society.

The metacognitive strategy was the second most popular strategy; most students recognized their mistakes in speaking English and were eager to correct them; they worked to learn how to be better English learners. Furthermore, most students stated that they had specific goals in mind to improve their English skills. The students' predilection for employing metacognitive strategies may be linked to their age and 
educational level. (Lightbown \& Spada, 2021) Assume that adult learners use planning strategies and adjustment in learning, as observed in this study, where respondents were fourth-year undergraduate students. In short, older students are more efficient than younger students.

The effective approach was the third most popular strategy. Even though they were worried about their English skills, the students encouraged themselves to use English; They tried to relax anytime they were nervous about using English, and they frequently shared their feelings about learning English with others. In this study, the third-year college students' favored memory approach comprised forming connections between new current material and prior ones, between what they knew and what they didn't know, connecting a word's sound and visual, and employing new words in phrases. The fact that this type of strategy is less popular may be related to the participants' level. Memory strategy is frequently linked to the learning strategies utilized at the beginning stage of language learning, according to (R L Oxford, 2001). The participants in this study were not beginners when it came to English; the participants were third-year college students who had learned English for more than ten years since they were in elementary school, which is why this strategy was not frequently chosen and used by the participants.

The participants' least favored strategies were cognitive and compensatory. Imitating native speakers speaking and enjoying Englishlanguage TV episodes or movies are all examples of cognitive strategies. Finally, per (Al-Hebaishi, 2012b) According to researchers at Taibah University, the last rank of English language learning strategies used by students was compensation strategy, which allows learners to use new information despite knowledge gaps. The compensation strategy includes using gestures to help English conversations run smoothly, inventing new vocabulary, as well as using synonyms for words or phrases that they do not know the correct ones in English. The participants' English environment may account for their lack of preference for these two strategies. English is a foreign language for the participants, which means they are surrounded by non-native speakers and are not forced to use English.

In addition to the aforementioned strategies, in the interview, the researcher asked the participants about the best ways they used in learning English, how they coped with the difficulties of understanding or using English as well as the use of avoidance strategies as the strategies which were not included in SILL questionnaire. The researcher classified their responses into two kinds of strategies; functional practice strategies and avoidance strategies. The three interviewees gave similar answers. 
They said that they used to ask friends or lecturers, browse from the internet such as YouTube and Google Translation, and use a dictionary. These are the excerpts of their responses in the interview:

"Listening to music is the best way of learning English". (S 14)

"I usually ask my friend when getting difficulties to understand or using English". (S 14)

"Having an English course, joining an English club, asking questions to the English lecturer or friends, using Google translation might be the best ways of learning English but personally I like watch YouTube about English grammar and pronunciation". (S 35)

"I usually write notes, guess from the context and dictionary to understand English better". (S 15)

It could be seen from the extracts above that the students had their ways for example listening to music, watching English YouTube, writing notes, guessing meaning, having English course or English club, and using dictionary or Google translation to understand English and to solve the problem they faced in understanding English. In short, the students actively found and created opportunities to use or practice English functionally. This strategy enabled students to understand English better and to increase their English skills. In other words, they seemed to use a functional practice strategy.

During the interview, the researcher also asked the participants if they would avoid or abandon English messages, topics, or concepts due to language difficulties. In responding to this question, none of the responses of the students showed that they would avoid or abandon English even if they found difficulties in it. The answers of the students showed that they would try anyways to understand the messages or topic areas of English such as "I sometimes keep it in mind, write or underline the words or sentences then try to understand it better at home" (S 15). The other two responses also show the similar thing, "If I don't get the messages or topic of English being talked, I will ask my friend or find from the dictionary" (S 35), "I will try to understand it by myself then ask my friend whenever I get stuck" (S 14).

Based on the above citation, it is known that the students would try to understand English messages, topics areas, or concepts as possible as they could. It revealed that they would not avoid or abandon English whenever they got difficulties in it. Overall, the students' preference in using strategies should be highly related to the course level of the participants. The participants in the current research were in preintermediate-to-intermediate level and have been learning English for 
about 10 years since they were in elementary school and Griffiths (2003) in (Griffiths, 2004) discovers that these students use learning strategies more frequently, particularly for interacting with others, utilizing available resources, and managing feelings and learning The current study's findings corroborated the previous study such as (Al-Hebaishi, 2012a; M.-H. M. Su, 2005) where participants were also college students, the participants used social strategy as the most and compensation strategies as the least. However, the findings were not consistent with (Chang, Ching-yi \& Shen, 2010) who researched junior high school students and the compensation strategies found as the most preferred strategies.

\section{The correlation of English language learning strategies and academic achievement in English}

In determining the relationship between English language learning strategies and English academic achievement, it has been discovered that the scores of the Strategy Inventory for Language Learning (SILL) correlate positively and significantly with the students' English scores $(\mathrm{r}=.463, \mathrm{p}=.001 .05)$.

Table 1 shows the relationship between SILL scores and English fifth-semester grades.

Table 1. Correlations

\begin{tabular}{|ll|c|c|}
\hline & & SILL_Scores & English_Scores \\
\hline SILL_Scores & Pearson & 1 & $.463^{*}$ \\
& Correlation & & \\
& Sig. (2-tailed) & & .001 \\
N & 50 & 50 \\
\hline English_Scores & Pearson & .463 & 1 \\
& Correlation & & \\
Sig. (2-tailed) & .001 & \\
N & 50 & 50 \\
\hline
\end{tabular}

${ }^{*}$ Correlation is significant at the 0.05 level (2-tailed).

In general, the finding was in line with those of (Al-Hebaishi, 2012a; Al-Qahtani, 2013; Angelianawati, 2012; Jhaish, 2010; Sioson, 2011; Solak \& Cakir, 2015; M.-H. M. Su, 2005; Uslu et al., 2016) where all agreed that learning strategies helped students in learning and absorbing the English subjects, The more pupils employed learning strategies, the higher their English achievement. It was shown that the students who used strategies 
more frequently and appropriately should have higher academic achievement in English. In a nutshell, strategy is one of the most important factors influencing students' academic performance. This finding supported (A. Chamot, 2004) who states, some researchers find students' learning strategies are helpful ways to assist Language students who are less successful in improving their performance. (Rebecca L Oxford, 2003a) emphasizes that when the learners consciously choose the appropriate strategies which met their learning style, these strategies then serve as an excellent toolkit for active, conscious, and intentional self-regulation of learning.

The Pearson Correlation was also used to examine the relationship between the six learning strategy subcategories and English academic achievement. All of the learning strategies correlated positively with English scores. 
Table 4.6. The relationship between six types of learning strategies and academic achievement in English

\begin{tabular}{|c|c|c|c|c|c|c|c|c|}
\hline & & Memory & Cognitive & \begin{tabular}{|l|} 
Compens \\
ation
\end{tabular} & $\begin{array}{l}\text { Metacogn } \\
\text { itive }\end{array}$ & Affective & Social & $\begin{array}{l}\text { English } \\
\text { Scores }\end{array}$ \\
\hline \multirow{3}{*}{ 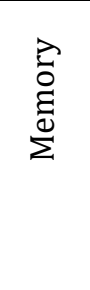 } & $\begin{array}{l}\text { Pearson } \\
\text { Correlati } \\
\text { on }\end{array}$ & 1 & .405 & .401 & .447 & .452 & .466 & .236 \\
\hline & $\begin{array}{l}\operatorname{Sig}(2- \\
\text { tailed })\end{array}$ & & .003 & .004 & .001 & .001 & .001 & .099 \\
\hline & $\mathrm{N}$ & 50 & 50 & 50 & 50 & 50 & 50 & 50 \\
\hline \multirow{3}{*}{ ن } & $\begin{array}{l}\text { Pearson } \\
\text { Correlati } \\
\text { on }\end{array}$ & .405 & 1 & .443 & .608 & .079 & .530 & $.481^{*}$ \\
\hline & $\begin{array}{l}\text { Sig. (2- } \\
\text { tailed) }\end{array}$ & .004 & & .001 & .000 & .587 & .000 & .000 \\
\hline & $\mathrm{N}$ & 50 & 50 & 50 & 50 & 50 & 50 & 50 \\
\hline \multirow[t]{3}{*}{ 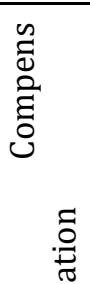 } & $\begin{array}{l}\text { Pearson } \\
\text { Correlati } \\
\text { on }\end{array}$ & .401 & .443 & 1 & .546 & .101 & .313 & $.389 *$ \\
\hline & $\begin{array}{l}\text { Sig. (2- } \\
\text { tailed) }\end{array}$ & .004 & .001 & & .000 & .486 & .027 & .005 \\
\hline & $\mathrm{N}$ & 50 & 50 & 50 & 50 & 50 & 50 & 50 \\
\hline \multirow[t]{3}{*}{ 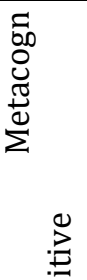 } & $\begin{array}{l}\text { Pearson } \\
\text { Correlati } \\
\text { on }\end{array}$ & .447 & .608 & .546 & 1 & .212 & .531 & $.398^{*}$ \\
\hline & $\begin{array}{l}\text { Sig. (2- } \\
\text { tailed) }\end{array}$ & .001 & .000 & .000 & & .139 & .000 & .004 \\
\hline & $\mathrm{N}$ & 50 & 50 & 50 & 50 & 50 & 50 & 50 \\
\hline \multirow[t]{3}{*}{ 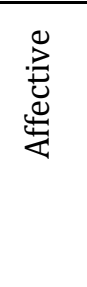 } & $\begin{array}{l}\text { Pearson } \\
\text { Correlati } \\
\text { on }\end{array}$ & .452 & .079 & .101 & .212 & 1 & .200 & .064 \\
\hline & $\begin{array}{l}\text { Sig. (2- } \\
\text { tailed) }\end{array}$ & .001 & .587 & .486 & .139 & & .164 & .659 \\
\hline & $\mathrm{N}$ & 50 & 50 & 50 & 50 & 50 & 50 & 50 \\
\hline \multirow{3}{*}{ 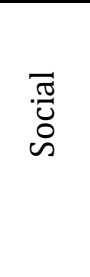 } & $\begin{array}{l}\text { Pearson } \\
\text { Correlati } \\
\text { on }\end{array}$ & .466 & .530 & .313 & .531 & .200 & 1 & .262 \\
\hline & $\begin{array}{l}\text { Sig. (2- } \\
\text { tailed) }\end{array}$ & .001 & .000 & .027 & .000 & .164 & & .066 \\
\hline & $\mathrm{N}$ & 50 & 50 & 50 & 50 & 50 & 50 & 50 \\
\hline
\end{tabular}


Hayati, Usman: The Study of Strategies In Learning English And English Academic

Achievement - 361

\begin{tabular}{|c|c|c|c|c|c|c|c|c|}
\hline $\begin{array}{l}n \\
\frac{1}{1} \\
: 0 \\
a \\
a\end{array}$ & $\begin{array}{l}\text { Pearson } \\
\text { Correlati } \\
\text { on }\end{array}$ & .236 & .481 & .389 & .396 & .063 & .262 & 1 \\
\hline 巳ัల & $\begin{array}{l}\text { Sig. (2- } \\
\text { tailed) } \\
\mathrm{N}\end{array}$ & $\begin{array}{r}.099 \\
0\end{array}$ & . & . & . & . & ${ }_{50}^{.066}$ & 50 \\
\hline
\end{tabular}

${ }^{*}$ Correlation is significant at the 0.05 level (2-tailed).

Concerning each classification of language learning strategy, cognitive strategy was the most significant and had a positive relationship with English academic achievement. $(r=.481, \mathrm{p}=.000<.05)$ followed by metacognitive $(r=.398, p=.004<.05)$, compensation $(r=.389, p=.005<.05)$ strategies. However, social ( $r=.262, p=.066>.05)$, memory $(r=.236, p=.099$ $>.05)$, and affective $(r=.064, p=.659>.05)$ strategies were insignificantly related to the students' English academic achievement

Students used cognitive strategies to manipulate language material indirect ways, allowing them to understand and analyze the target language. These strategies were found to be positively and significantly related to students' success in language learning $(r=.481, p=.0000 .05)$. The findings were consistent with the findings of (Solak \& Cakir, 2015) and Ehrman and Oxford (1995) in (Griffiths, 2004). It was discovered that the more students used cognitive strategies including imitating English speakers speaking and writing new Vocabulary, the greater their English accomplishment would be.

Another kind of language learning strategy that also correlated with the students' English academic achievement positively and significantly $(r=.398, p=.004<0.05)$ was the metacognitive strategy where the students used this strategy to manage their language. This study's findings of a strong and favorable relationship between metacognitive strategy and English educational success are consistent with those of O'Malley et al (1985) in (Griffiths, 2004), who discovered that students with higher levels of education used metacognitive strategy more frequently. Furthermore, Rubin and Thompson (1982), as cited in (D. H. Brown, 2007), assert that a good language student will seize and/or maximize all opportunities to practice English. inside and outside of the classroom, make errors work for them instead of against them, and organize language information

Compensation strategies were the third language learning strategy that significantly and positively correlated with students' English academic achievement. Conducting similar research in 1995, Oxford and Ehrman as cited in (Rebecca L Oxford, 2003a) also demonstrated that 
compensation strategy was significantly related to L2 proficiency. To sum up, Compensation strategies like guessing the meaning from context utilizing linguistic or other key information, and resolving barriers in speaking and writing by switching to the native language, seeking assistance, using body gestures or expression, etc, all contributed to the students' academic achievement.

Furthermore, the researcher found that the social strategy was the fourth language learning strategy that had positive but insignificant to the English academic achievement of the students. Learners' actions to assist students in working with others and understanding the culture of the target language, and the language itself, are referred to as social strategy. The insignificant correlation showed by the finding of the current study was not consistent with (Uslu et al., 2016) who found this kind of strategies correlated significantly with the students' outcomes. The causes for the disparities in performance could be linked to nationality where (Uslu et al., 2016) The previous study was conducted on students from Turkey, whereas the current study is being undertaken on Indonesian students. (Politzer \& McGroarty, 1985) and (O'malley et al., 1990) stated that the nationality of the learners might influence their choice of using strategies in learning a language.

Memory strategy was the fifth strongest strategy related to students' English academic achievement. This strategy assists students in connecting one language or concept to another. Students who make mental associations, use images and sounds, review thoroughly, and take action are the types of memory strategies that were discovered to be the second strategy that was insignificantly correlated with English academic achievement. One possible explanation for the insignificant correlation is those memory strategies are typically used in the early stages of language learning, implying that learners rarely used such strategies as their vocabulary and structures grew larger. (Rebecca L Oxford, 2003b) .

Finally, effective strategies had the weakest relationship with students' academic achievement in the current study. Affective strategies such as talking and writing about feelings, rewards, and anxiety levels were positively but insignificantly related to the students' English academic achievement. In contrast, Mullins (1992) in (Rebecca L Oxford, 2003b) who conducted the study on Thai EFL students discovered that affective strategies linked negatively with some measures of students' outcomes. One of the reasons was because, for some students who were in progress toward learning outcomes, the need of using effective strategies was not quite big anymore. 
In brief, the current study agreed with some previous researches (Al-Hebaishi, 2012a; Al-Qahtani, 2013; Angelianawati, 2012; Jhaish, 2010; Sioson, 2011; Solak \& Cakir, 2015; M.-H. M. Su, 2005; Uslu et al., 2016) that The use of language learning strategies correlates with students' academic achievement in language. Sterm (1975) in (Griffiths, 2004) supports the findings of the recent study, stating that competent language learners have positive learning techniques. Similarly, Presley \& Associates (1990) in (Rebecca L Oxford, 2003b), claim that using learning strategies is demonstrably related to student accomplishment.

The relationship between language learning strategies and language outcomes should be given more attention to help language students learn the target language more successfully and effectively. Furthermore, teachers and parents should introduce or use a variety of learning strategies to assist students in locating the most appropriate English language learning strategies to help them improve their English achievement. As Ehrman and Oxford (1995) in (Kuo Lee, 2010) reports that successful students used multiple types of methods more frequently and appropriately than slow learners,

\section{CONCLUSION}

The current study's findings clearly showed that third-year college students majoring in English at IAIN Samarinda used an English language learning strategy. The students' favored strategy was the metacognitive technique, which includes indirect strategies. When it came to the association between English learning strategies and English academic accomplishment, both variables were shown to be positively connected.

Since the students had their own preferred strategies for learning English, and those strategies had a positive link with the students' English academic accomplishment, it is believed that the findings of this study will be useful in educational settings.

\section{REFERENCE}

Al-Hebaishi, S. M. (2012a). Investigating the relationships between learning styles, strategies, and the academic performance of Saudi English majors. International Interdisciplinary Journal of Education, 1(1028), 1-11. 
Al-Hebaishi, S. M. (2012b). Investigating the Relationships between Learning Styles, Strategies and the Academic Performance of Saudi English Majors. International Interdisciplinary Journal of Education, 1(8), 510-520. https://doi.org/10.12816/0002890

Al-Qahtani, M. F. (2013). Relationship between English Language, Learning Strategies, Attitudes, Motivation, and Students' Academic Achievement. Education in Medicine Journal, 5(3).

Angelianawati, L. (2012). THE CONTRIBUTION OF STUDENTS BELIEFS ABOUT LANGUAGE LEARNING, LEARNING STYLES, AND LANGUAGE LEARNING STRATEGIES TOWARD THE ENGLISH ACHIEVEMENT OF THE ELEVENTH GRADE STUDENTS OF STATE SENIOR HIGH SCHOOLS IN SINGARAJA. Jurnal Pendidikan Dan Pembelajaran Bahasa Indonesia, 1(2).

Apriani, E. (2017). Utilizing Preservice English Teachers Strategies and Classroom Management at Junior High School in Rejang Lebong Regency. ENGLISH FRANCA: Academic Journal of English Language and Education, 1(2), 149-194.

Brown, D. (2007). Language Assessment Principles and Classroom Articles. San Francisco: San Francisco State University.

Brown, D. H. (2007). Principles of language learning \& teaching. (5th Eds.). Pearson: Longman.

Chamot, A. (2004). Issues in language learning strategy research and teaching. Electronic Journal of Foreign Language Teaching, 1(1), 1426.

Chamot, A. U. (2004). Issues in language learning strategy research and teaching. Electronic Journal of Foreign Language Teaching, 1(1), 1426.

Chang, Ching-yi \& Shen, M. (2010). The effects of beliefs about language learning and learning strategy use of junior high school EFL learners in remote districts. Research in Higher Education Journal, 8(June), 18.

Ghavamnia, M., Kassaian, Z., \& Dabaghi, A. (2011). The Relationship between Language Learning Strategies, Language Learning Beliefs, Motivation, and Proficiency: A Study of EFL Learners in Iran. Journal of Language Teaching \& Research, 2(5).

Griffiths, C. (2004). Language-learning strategies: Theory and research. AIS St Helens, Centre for Research in International Education.

Hong-Nam, K., \& Leavell, A. G. (2006). Language learning strategy use of ESL students in an intensive English learning context. The system, $34(3), 399-415$.

Jhaish, M. A. (2010). The relationship among learning styles, language 
Hayati, Usman: The Study of Strategies In Learning English And English Academic Achievement - 365

learning strategies, and the academic achievement among the English majors at Al-Aqsa University.

Kuo Lee, C. (2010). an Overview of Language Learning Strategies. Articles, $7,132-152$.

Lan, Y. T. (2010). A study of Taiwanese 7th graders' foreign language anxiety, beliefs about language learning, and its relationship with their English achievement. Unpublished MA Thesis, Ming Chuan University.

Lee, C. K. (2010). An overview of language learning strategies. Annual Review of Education, Communication \& Language Sciences, 7.

Liao, P.-S., \& Chiang, M.-Y. (2004). How College Students' Beliefs about English Learning Relate to Their Strategy Use. 新竹師院學報, 19， 137-154.

Lightbown, P. M., \& Spada, N. (2021). How Languages Are Learned 5th Edition. Oxford university press.

O'malley, J. M., O'Malley, M. J., Chamot, A. U., \& O'Malley, J. M. (1990). Learning strategies in second language acquisition. Cambridge university press.

Oxford, R L. (2001). Language Learning Style and Strategies; Teaching English as a Second or Foreign Language, edited by Marianne CelceMurcia. United States: Heinle \& Heinle.

Oxford, Rebecca L. (2003a). Language Learning Styles and Strategies : an Overview. Learning, 1-25.

Oxford, Rebecca L. (2003b). Language learning styles and strategies: An overview.

Politzer, R. L., \& McGroarty, M. (1985). An exploratory study of learning behaviors and their relationship to gains in linguistic and communicative competence. Tesol Quarterly, 19(1), 103-123.

Richards, J. C., Richards, J. C., \& Renandya, W. A. (2002). Methodology in language teaching: An anthology of current practice. Cambridge university press.

Saeb, F., \& Zamani, E. (2013). Language Learning Strategies and Beliefs about Language Learning in High-School Students and Students Attending English Institutes: Are They Different?. English Language Teaching, 6(12), 79-86.

Sioson, I. C. (2011). Language learning strategies, beliefs, and anxiety in the academic speaking task. Philippine ESL Journal, 7(1), 3-27.

Solak, E., \& Cakir, R. (2015). Language learning strategies of language elearners in Turkey. E-Learning and Digital Media, 12(1), 107-120.

$\mathrm{Su}$, M.-H. M. (2005). A Study of EFL Technological and Vocational College Students' Language Learning Strategies and their Self-Perceived 
English Proficiency. Electronic Journal of Foreign Language Teaching, 2(1), 44-56.

$\mathrm{Su}, \mathrm{M} . \mathrm{M}$. (2005). A study of EFL technological and vocational college students' language learning strategies and their self-perceived English proficiency. Electronic Journal of Foreign Language Teaching, 2(1), 44-56.

Suwanarak, K. (2012). English language learning beliefs, learning strategies, and achievement of master's students in Thailand. TESOL in Context, November 2012.

Uslu, M. E., Sahin, E., \& Odemis, I. S. (2016). The effect of language learning strategies on academic achievement. Journal of Educational and Instructional Studies in the World, 6(3), 73-78.

Yang, N. D. (1999). The relationship between EFL learners' beliefs and learning strategy use. A system, 27(4), 515-535. https://doi.org/10.1016/S0346-251X(99)00048-2 
Hayati, Usman: The Study of Strategies In Learning English And English Academic Achievement - 367 